\title{
The Role of Cholinergic Midbrain Neurons in Startle and Prepulse Inhibition
}

\author{
Erin Azzopardi, Andrea G. Louttit, Cleusa DeOliveira, Steven R. Laviolette, and $\$ Susanne Schmid \\ Anatomy and Cell Biology, Schulich School of Medicine and Dentistry, University of Western Ontario, London, Ontario N6A 5C1, Canada
}

One of the two major cholinergic centers of the mammalian brain is located in the midbrain, i.e., the pedunculopontine tegmentum (PPTg) and the adjacent laterodorsal tegmentum. These cholinergic neurons have been shown to be important for e.g., arousal, reward associations, and sleep. They also have been suggested to mediate sensorimotor gating, measured as prepulse inhibition of startle (PPI). PPI disruptions are a hallmark of schizophrenia and are observed in various other psychiatric disorders, where they are associated with, and often predictive of, other cognitive symptoms. PPI has been proposed to be mediated by a short midbrain circuitry including inhibitory cholinergic projections from PPTg to the startle pathway. Although the data indicating the involvement of the PPTg is very robust, some more recent evidence challenges that there is a cholinergic contribution to PPI. We here use transient optogenetic activation of specifically the cholinergic PPTg neurons in male and female rats to address their role in startle modulation in general, and in PPI specifically. Although we could confirm the crucial role of PPTg cholinergic neurons in associative reward learning, validating our experimental approach, we found that activation of cholinergic PPTg neurons did not inhibit startle responses. In contrast, activation of cholinergic PPTg neurons enhanced startle, which is in accordance with their general role in arousal and indicate a potential involvement in sensitization of startle. We conclude that noncholinergic PPTg neurons mediate PPI in contrast to the longstanding hypothetical view that PPI is mediated by cholinergic PPTg neurons.

Key words: cholinergic; neurocircuitry; prepulse inhibition; sensorimotor gating; startle

\section{Significance Statement}

Activation of cholinergic neurons in the midbrain has been assumed to mediate prepulse inhibition of startle (PPI), a common measure of sensorimotor gating that is disrupted in schizophrenia and other psychiatric disorders. We here revisit this longstanding hypothesis using optogenetic activation of these specific neurons combined with startle testing in rats. In contrast to the hypothetical role of these neurons in startle modulation, we show that their activation leads to an increase of baseline startle and to prepulse facilitation. This supports recent data by others that have started to cast some doubt on the cholinergic hypothesis of PPI, and calls for a revision of the theoretical construct of PPI mechanisms.

\section{Introduction}

The PPTg is an evolutionary highly conserved cholinergic midbrain center and an important component of the ascending reticular activating system. The PPTg is highly interconnected with the basal ganglia, cerebellum, and thalamus, as well as with dopaminergic centers in the brain. It is one of the targets for deep

\footnotetext{
Received April 17, 2018; revised Aug. 1, 2018; accepted Aug. 20, 2018.

Author contributions: E.A. wrote the first draft of the paper; C.D., S.R.L., and S.S. edited the paper; E.A.,S.R.L., and S.S. designed research; E.A., A.G.L., and C.D. performed research; E.A., A.G.L., and C.D. analyzed data; S.S. wrote the paper.

This work was supported by the Natural Sciences and Engineering Council of Canada.

The authors declare no competing financial interests.

Correspondence should be addressed to Dr. Susanne Schmid, Anatomy and Cell Biology, Schulich

School of Medicine and Dentistry, University of Western Ontario, London, ON N6G 1R3, Canada. E-mail: Susanne.Schmid@schulich.uwo.ca.

DOI:10.1523/JNEUROSCI.0984-18.2018

Copyright $\odot 2018$ the authors $\quad 0270-6474 / 18 / 388798-11 \$ 15.00 / 0$
}

brain stimulation in Parkinson disease (Garcia-Rill et al., 2015), however, in recent years it has become evident that the PPTg is not only a locomotor center, but also important for arousal, REM sleep, and cognitive function, e.g., attention, associative reward learning, reward prediction error processing, and decision making (Alderson et al., 2004; Winn, 2008; Steidl et al., 2011; Thompson and Felsen, 2013; Cyr et al., 2015; Gut and Winn, 2016; Mori et al., 2016; Xiao et al., 2016). In this context, the idea that PPTg promotes orienting responses toward a (prepulse) stimulus, e.g., eye saccades and/or head turns, while inhibiting avoidance responses such as startle, is very compelling (Yeomans, 2012). Prepulse inhibition of startle (PPI) describes such an attenuation of startle responses when a startle stimulus is preceded by another sensory stimulus (prepulse) by 20-500 ms. It can therefore be viewed as an early action selection mechanism that allows a subject to orient toward the prepulse while inhibiting other, potentially interfering, avoidance responses (Yeomans, 2012). PPI 


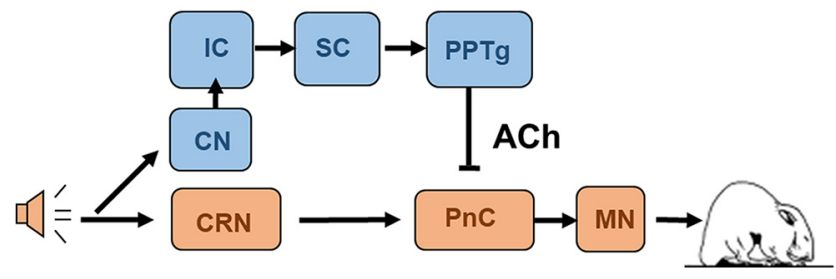

Figure 1. Hypothetical PPI pathway. The hypothetical primary startle pathway (orange) is short and includes the cochlear root neurons (CRNs), and giant neurons in the PnC that directly innervate cervical and spinal motor neurons (MNs). Inhibition of this pathway by prepulses is assumed to occur on the level of the $\mathrm{PnC}$ (caudal pontine reticular formation) (blue pathway): non-startling acoustic prepulses are processed through the ascending auditory pathway including the cochlear nucleus ( $\mathrm{CN}$ ) and the inferior colliculus (IC). From there, auditory information is signaled to the multisensory superior colliculus (SC) and the PPTg. Cholinergic inhibitory projections from the PPTg to the PnC have been suggested to mediate PPI (modified from Koch, 1999).

measurements have been originally developed in humans for assessing sensorimotor gating disruptions in people with schizophrenia (Braff et al., 1978, 1995; Geyer and Braff, 1982; Kunugi et al., 2007; Walters and Owen, 2007; Takahashi et al., 2008; Moriwaki et al., 2009; Perry et al., 2009), however, several other psychiatric disorders are also associated with disruptions in PPI, e.g., autism spectrum disorders, obsessive compulsive disorder, and others (Swerdlow et al., 1995; Castellanos et al., 1996; Braff et al., 2001). PPI disruptions have been shown to be associated with other cognitive disruptions in affected people, most importantly, with attentional problems (Green, 1996; Fenton et al., 2003; Sinclair et al., 2017). Although the reversal of dopamine-induced PPI deficits in rats or mice is a gold standard for antipsychotic drug screening in the pharmaceutical industry, none of the common antipsychotics show consistent and robust positive effects on PPI in affected people.

For decades, PPI has been assumed to be a function of mesopontine cholinergic projections inhibiting the startle pathway on the level of the pons (Fig. 1). This was primarily based on studies reporting that general lesions of the PPTg greatly disrupt PPI (Koch et al., 1993; Swerdlow and Geyer, 1993). However, the majority of neurons in the PPTg are noncholinergic, i.e., GABAergic or glutamatergic (Wang and Morales, 2009). Furthermore, although there is a plethora of in vivo and in vitro evidence that seem to corroborate a role of acetylcholine in modulating the startle pathway (Fendt and Koch, 1999; Koch, 1999; for review, see Fendt et al., 2001; Bosch and Schmid, 2006, 2008; Pinnock et al., 2015), the functional role of this cholinergic modulation, i.e., whether it contributes to PPI or rather modulates general startle reactivity, has never been tested. However, it was recently reported that a conditional knock-out of cholinergic function in the midbrain caused mice to have improved PPI (Machold, 2013). In another study, specific lesions of cholinergic midbrain neurons by a fusion toxin left PPI mainly intact, while profoundly reducing general startle magnitude (MacLaren et al., 2014). Although there are downsides of chronic lesions in terms of compensatory processes, these latter two studies certainly provide some evidence that is conflicting with the traditional view on the role of PPTg cholinergic neurons in PPI. We here revisit the hypothesis that PPTg cholinergic neurons mediate PPI, by transient and specific activation of these neurons using optogenetic stimulation in a transgenic ChAT::Cre rat during startle testing.

\section{Materials and Methods}

Subjects. A hemizygous transgenic rat line was used [Long-Evans-Tg(Chat-Cre)5.1Deis; RRRC\#00658, Rat Resource and Research Center,
Columbia, MO], with a bacterial artificial chromosome containing the mouse ChAT gene with a Cre insertion before the ATG of the ChAT promoter. This strain is estimated to carry six copies of the transgene (Witten et al., 2011) and was maintained by breeding a carrier male with a wild-type (WT) Long-Evans female. Animals were genotyped at the age of 4-6 weeks via tissue punches taken from the ear and performing PCR. Procedure and primers are described by Witten et al. (2011).

Animals were cared for according to the ethical guidelines of the University of Western Ontario Animal Use Subcommittee and Canadian Council on Animal Car. For the first 8-10 weeks of age, animals were group housed. Following surgery, animals were individually housed. Rats were given ad libitum food and water, and maintained on a $12 \mathrm{~h}$ light/ dark cycle. All testing occurred during the light phase.

Testing of the acoustic startle response. Testing of the acoustical startle response (ASR) was completed in an enclosed sound-attenuated startle box from MED Associates (MED-ASR-PRO1). Transgenic and WT animals were placed into small transparent tubes $(25 \times 12 \mathrm{~cm})$ mounted on a movement-sensitive platform. A piezoelectric transducer mounted below the platform converted the vertical displacement of the platform induced by a startle response into a voltage signal. Startle amplitude was determined using the amplitude of the largest positive and negative peaks of the signal measured in a $300 \mathrm{~ms}$ window after the presentation of the acoustic stimulus. Determination of the amplitude was done by MED Associates' software (Startle Reflex v6.0). For a schematic representation of ASR testing, see Figures $2 A, 3 A$, and $5 A$. Before testing, animals were acclimated to the startle box for $5 \mathrm{~min}$ for 2 subsequent days. During this acclimation, and throughout each test session, there was a $65 \mathrm{~dB}$ SPL white-noise background sound. On Day 3 rats were tested on an input/ output (I/O) function to assess startle reactivity. After a 5 min acclimation period, this test began with the presentation of a $65 \mathrm{~dB}$ SPL white noise $(20 \mathrm{~ms})$ and increased to $120 \mathrm{~dB}$ SPL, in $5 \mathrm{~dB}$ SPL steps at an intertrial interval (ITI) of $20 \mathrm{~s}$. Startle reactivity determined the setting of the gain of the movement-sensitive platform (Valsamis and Schmid, 2011). This gain amplified the signal from the platform to ensure animals startled within a detectable range. Once a subject's gain was determined, it was kept constant throughout the remaining days of testing. The I/O was completed at a gain of 1 for all animals. Following the I/O, experimental testing started: following a 5 min acclimation, animal startle responses were habituated by 30 startle-alone trials ( $20 \mathrm{~ms}$ white noise, 105 $\mathrm{dB}$ SPL, $20 \mathrm{~s}$ ITI). The following PPI test consisted of seven different trial types ( 10 trials/condition, total $=70$ trials, pseudorandomized order). The trial conditions were as follows: startle pulse-alone trials (for baseline startle amplitude) and combinations of two different prepulses (75 or 85 $\mathrm{dB}$ SPL white noise; $4 \mathrm{~ms}$ ) at three different interstimulus intervals (ISIs; 15,30 , or $100 \mathrm{~ms}$ ). The ITI for this block varied between 15 and $25 \mathrm{~ms}$.

For combined optogenetic stimulation, animals were tested in a clear, rectangular holding chamber (w: $25 \mathrm{~cm}, \mathrm{~h}: 30 \mathrm{~cm}$ ), placed in a partially enclosed startle box. This ensured the rat was comfortably tethered to the light emitting diode (LED), which was suspended on top of the box. The light source was connected to the animal using a branching optopatchcord (400/430 $\mu \mathrm{m}$ core, $0.48 \mathrm{NA}$, Doric Lenses). Before testing, animals were acclimated to the tether procedure. Animals were tethered two times ( $15 \mathrm{~min}$ ) while freely exploring their home cages. During their first exposure to the startle chambers, animals were not tethered (15 $\mathrm{min}$ ), however, for the following three acclimation procedures they were tethered to the light source but received no photostimulation. Because tethering required the use of a larger holding chamber during startle testing, the acclimation procedure was lengthened to $15 \mathrm{~min}$ to reduce movement artifacts during testing. Optogenetic stimulation was triggered by a $28 \mathrm{~V}$ signal from the Med Associates boxes, which was transformed using a converter (SG231, Med Associates) into a TTL-pulse. This TTL-pulse triggered a waveform generator (DG1022, Rigol Technologies), which was used to modulate light stimulation. The waveform generator triggered the LED driver (LED RV 1Ch 1000 Single LED, Doric Lenses), which controlled the LED light fiber. Light stimulation was delivered using a blue LED (465 nm, FRJ $1 \times 1$, Doric Lenses) at $50 \mathrm{~Hz}(3$ pulses of $15 \mathrm{~ms}$ of light, $5 \mathrm{~ms}$ rest). For a dose/response curve, lower stimulation frequencies were also tested: $10 \mathrm{~Hz}$ (3 pulses of $15 \mathrm{~ms}, 85 \mathrm{~ms}$ rest) and $1 \mathrm{~Hz}$ (3 pulses of $15 \mathrm{~ms}$ ). These frequencies were selected based 
A
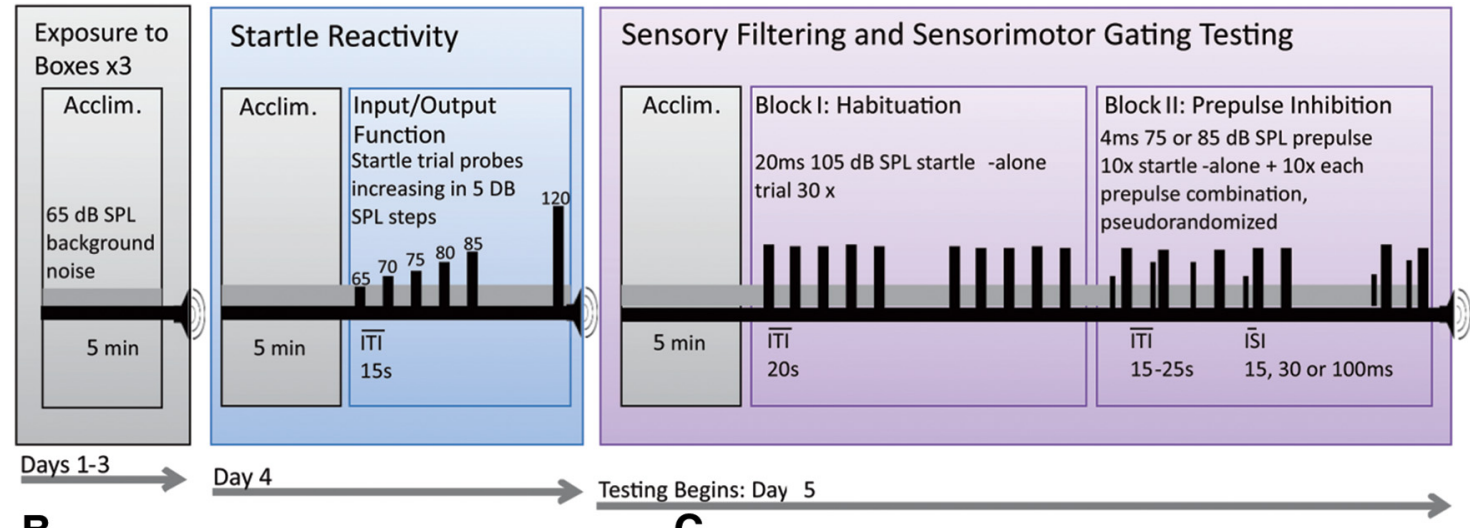

B

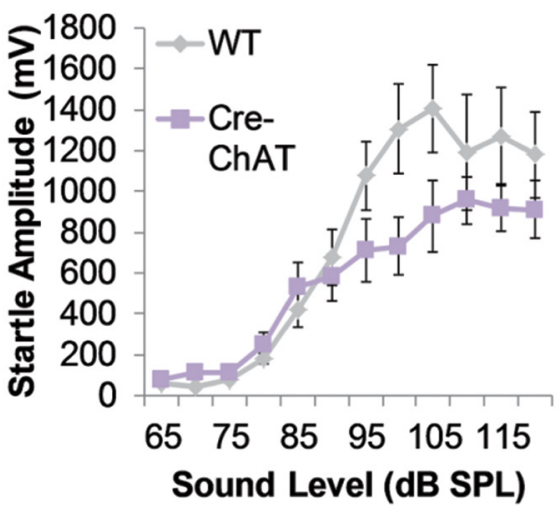

C

D

E
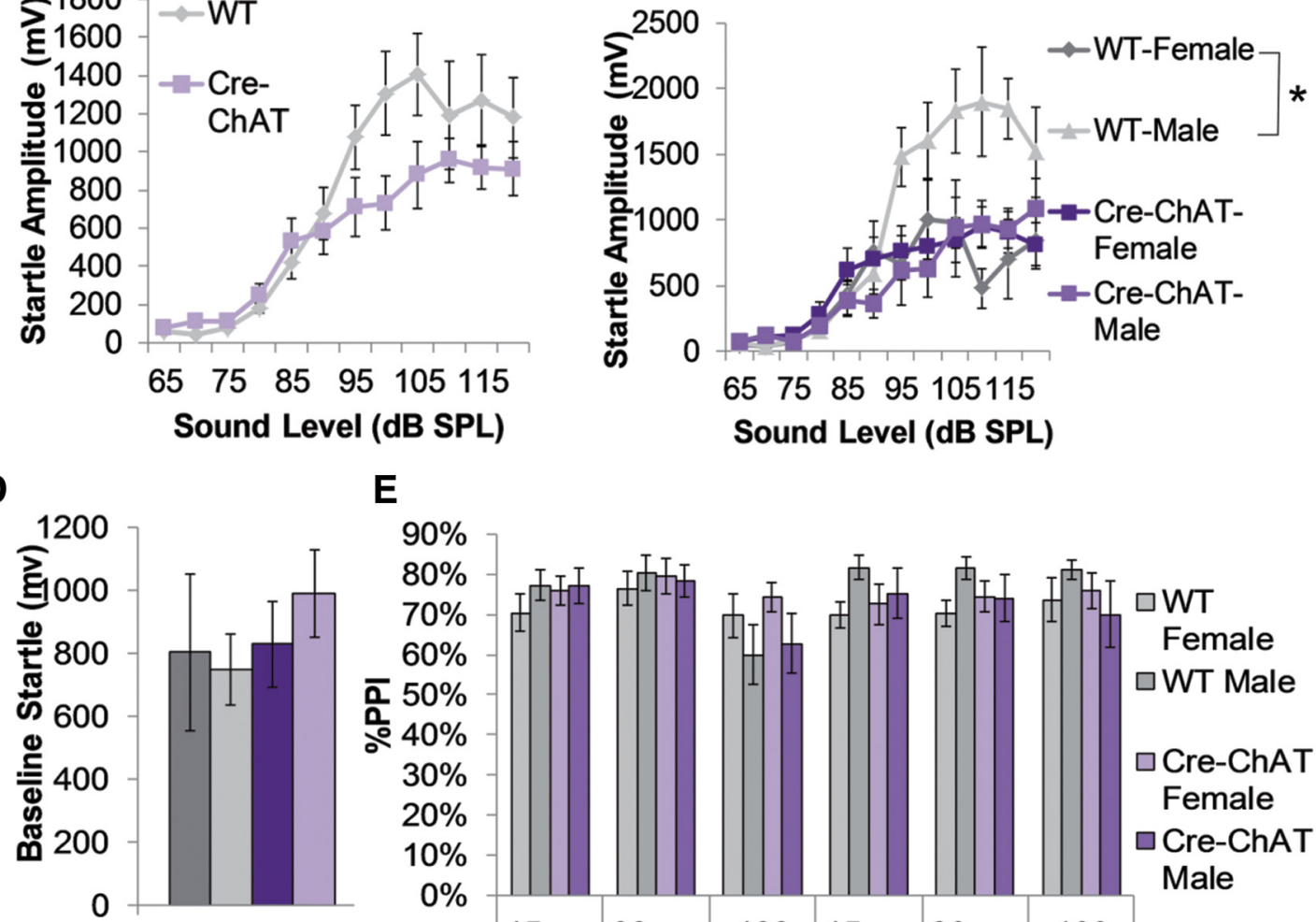

Figure 2. ChAT::Cre rats exhibits normal startle and PPI. $A$, Scheme of startle testing protocol. $B$, Startle responses to increasing sound levels (I/O function). Both genotypes show a similar startle threshold between 80 and $85 \mathrm{~dB}$. There was no main effect of $\operatorname{sex}\left(F_{(1,27)}=2.2, p=0.15\right)$ or genotype $\left(F_{(1,27)}=2.2, p=0.15\right)$, but a significant sex by genotype interaction $\left(F_{(1,27)}=5.6, p=\right.$ $0.03)$; ChAT:::Cre $n=16$ (7 males 9 females), WT $n=16$ (8 males, 8 females). C, WT males had a higher startle amplitude than the other animals $\left(F_{(1,14)}=6.4, p=0.02\right) . D, A f t e r$ habituation, there were no differences between groups in baseline startle (startle-only trials) during PPI testing (genotypes: $F_{(1,27)}=0.72, p=0.40 ;$ sex: $\left.F_{(1,27)}=0.28, p=0.60\right)$. E, There were no differences in PPI between groups (genotype: $F_{(1,27)}=0.03, p=0.86 ;$ sex: $\left.F_{(1,27)}=0.12, p=0.73\right)$. ${ }^{*} p<0.05$.

on seminal findings from Witten et al. (2011). Light illumination varied from 21 to $24.7 \mathrm{~mW}$. Optical power was measured using an energy meter console (PM100D paired with photodiode sensor S120C, Thorlabs).

For experiments with mecamylamine, all animals received an intraperitoneal injection of mecamylamine hydrochloride (3 mg/kg; M9020, Sigma-Aldrich) or saline, $7 \mathrm{~d}$ apart, before combined optogenetic stimulation and startle testing. During startle testing, the acclimation was shortened to $7 \mathrm{~min}$ to account for the half-life of the drug.

Locomotor behavior. Rats were placed into a $45 \times 45 \mathrm{~cm}$ box with two adjacent opaque walls and two adjacent translucent walls. The animals were able to freely explore the box for $20 \mathrm{~min}$ while they were tracked using a webcam and ANYmaze software v4.99 (Stoelting). Distance traveled and time spent in the center $(15 \times 15 \mathrm{~cm}$ centered square $)$ and surrounding perimeter was recorded. Additionally, the data for each animal was averaged in to 5 min blocks (total of 4 blocks).

Conditioned place preference. A subset of males ( $n=6 /$ group) underwent an unbiased, counterbalanced, conditioned place preference (CPP) procedure, as described previously in detail (Ahmad et al., 2013). In brief, saline vehicle or morphine sulfate injections ( $5 \mathrm{mg} / \mathrm{kg}$, i.p., MacfarlandSmith, administered immediately before placement in the chamber) were paired with one of two environments that differed in color (black or white), texture (smooth floor or textured with woodchip bedding), and smell ( $2 \%$ acetic acid or no added scent). As reported previously, rats display no baseline preference for either of these two environments (Laviolette and van der Kooy, 2003). For optogenetic CPP, all animals were tethered to the light source and received light stimulation whenever 
placed in the paired box. They did not receive any drug injections. Three days after the conditioning phase, animals were tested for a place preference: they were placed in a neutral zone between both chambers and could freely explore both chambers for $10 \mathrm{~min}$. The distance traveled and time spent in each compartment were recorded and tracked using a webcam and ANYmaze software v4.99 (Stoelting). For each animal, CPP behavior was assessed by the time spent in each compartment and using an individually calculated place preference score (time in morphinepaired environment/time in saline).

Surgical procedure. Animals (males and females, aged 10-14 weeks) were induced with a $5 \%$ isoflurane and $95 \%$ oxygen and maintained with a $2 \%$ isoflurane. A subcutaneous injection of meloxicam $(1 \mathrm{mg} / \mathrm{kg})$ and intramuscular injection of Baytril $(10 \mathrm{mg} / \mathrm{kg})$ were administered before surgery and as needed $7 \mathrm{~d}$ postsurgery for pain management. Bluntended ear bars and a snout mask were used to secure the head in the stereotaxic frame. A midline incision was made in the skin on top of the head, and bilateral burr holes were drilled at the following coordinates from bregma: $\pm 2.0 \mathrm{~mm}$ medial/laterally, $-7.2 \mathrm{~mm}$ ventrally, and -7.6 caudally. $1 \mu \mathrm{l} /$ side of virus solution were injected at a rate of $0.1 \mu \mathrm{l} / \mathrm{min}$ using a blunt end $1.0 \mu \mathrm{l}$ Hamilton syringe (Model 7001 KH SYR, Knurled Hub NDL, 25 gauge, 2.75 in, point style 3; Hamilton). The syringe rested for $1 \mathrm{~min}$ before injection and $7 \mathrm{~min}$ postinjection before retraction. For optogenetic experiments, bilateral fiber-optic cannulae $(7.2 \mathrm{~mm}, 400$ / $430 \mu \mathrm{m}$ core, NA 0.48; Doric Lenses) were lowered into the same location. Once in place, they were secured using acrylic dental cement. Three jeweler's screws were placed in the skull to improve security of the implants ( 2 bilaterally over the parietal skull bones and 1 on the left frontal skull bone). Silk suture was used to close the wound and rats were given a $21 \mathrm{~d}$ recovery period to promote maximal expression of the respective protein before testing began.

Viral constructs. For optogenetic stimulation, animals were stereotaxically microinjected with rAAV5-EF1 $\alpha$-DIO-hChR2(H134R)-eYFP $(4.3 \times 10 \mathrm{e} 12 \mathrm{vg} / \mathrm{ml}$; Lot:AV4313p, UNC Vector Core, Chapel Hill, NC). For controls, the following control virus was used: rAAV5-EF1 $\alpha$-DIOeYFP $(4.9 \times 10 \mathrm{e} 12 \mathrm{vg} / \mathrm{ml}$; Lot:AV4836c, UNC Vector Core $)$. Viruses were aliquoted and stored at $-80^{\circ} \mathrm{C}$.

Immunohistochemistry. Before perfusion, animals received bilateral $50 \mathrm{~Hz}$ light stimulation (25 pulses of $15 \mathrm{~ms}$ duration/min) for $30 \mathrm{~min}$. Animals were perfused $60-90 \mathrm{~min}$ after with saline followed by $4 \%$ paraformaldehyde. The brains were harvested and stored in 30\% sucrose until sliced into $40 \mu \mathrm{m}$ slices using a freezing microtome (KS34S, ThermoFisher Scientific). Slices were divided into four parallel series and stored at $-20{ }^{\circ} \mathrm{C}$ in cryoprotectant solution [ $30 \%$ sucrose, $30 \%$ ethylene glycol, and $5 \%$ of $0.01 \%$ sodium azide in $0.1 \mathrm{~m}$ phosphate buffer $(\mathrm{PB})]$.

Before free-floating immunohistochemistry being performed, as well as in between all incubations with antibodies, all slices were thoroughly rinsed in $0.1 \mathrm{M}$ PB. Antibodies were delivered in a $0.1 \mathrm{M} \mathrm{PB}$ and $0.1 \%$ bovine serum albumin (BSA) solution. Slices were pretreated with a $1 \%$ $\mathrm{H}_{2} \mathrm{O}_{2}$ in $0.1 \mathrm{M} \mathrm{PB}$ (Caledon Laboratories) for 10 min then blocked for $1 \mathrm{~h}$ in a $0.1 \mathrm{M}$ PB plus $0.4 \%$ Triton X-100 and $0.1 \%$ BSA (Fisher Scientific) solution before incubation with primary antibodies. Immunohistochemistry was performed using an antibody for c-FOS (1:1000; polyclonal rabbit, Sc-52, Santa Cruz Biotechnology) and a secondary antibody AlexaFluor 594 (donkey anti-rabbit, ThermoFisher Scientific), to ensure stimulation parameters activated target neurons. This validation of photostimulation has been used in the past (Liu et al., 2012; Yamamoto et al., 2015). To verify virus expression in cholinergic cells we used an antibody for choline transporter (ChT; 1:500; monoclonal mouse, EMD Millipore) and amplified this using ta standard ABC method and tagged this using Streptavidin AlexaFluor 594 conjugate (1:1000; ThermoFisher Scientific). Images were taken for each animal between postsurgery days $26-35$. For each animal, three representative images were taken at $20 \times$ magnification: one at the injection site, one posterior, and one anterior to the site within the same series. Coexpression with the fluorescent tag EYFP that labeled neurons expressing the ChR2(H134R) protein was quantified. Images were acquired using a Leica LSM 800 (Zeiss) confocal microscope using $20 \times$ and $40 \times$ magnification. Images were scanned using the 488 and $546 \mathrm{~nm}$ laser lines individually, and we collected wavelengths $490-550$ and 560-700 nm, respectively. Images were merged using Zen software (Zeiss). To estimate cellular activation with photostimulation, two individuals blinded to the groups counted the number of yellow fluorescent protein (YFP)-expressing neurons, and c-FOS-positive cells, as well as the number of YFP neurons that coexpressed c-FOS for both experimental (ChR2(H134R)-YFP) animals and controls (YFP only). Cell counts were tracked using ImageJ software using the Fiji cell counter plug-in (Schindelin et al., 2012; Schneider et al., 2012). The inter-rater reliability between counters was calculated using a two-way mixed effects model Intraclass correlation coefficient (ICC), which revealed an acceptable correlation (0.90). Once counted, an average of the two cell counts was used for reporting (C: 0.93). Once counted, an average of the two cell counts was used for reporting and analysis.

Statistical analysis. Startle testing: Levene's Test of Equality of Error Variance or Mauchley's Test of Sphericity (repeated-measures ANOVA only) was used before performing ANOVA. If Levene's test was violated, an equivalent nonparametric ANOVA was run. In the case of a repeatedmeasures ANOVA, if sphericity was violated, corrections were applied based on the $\varepsilon$ value (if $\varepsilon<0.75$ the Greenhouse-Geisser correction was applied, or if $\varepsilon>0.75$ the Huynh-Feldt correction was used). If post hoc tests were necessary, a Student's $t$ test with Bonferroni corrections was performed. Criterion for significance was $\alpha=0.05$. Three-way repeatedmeasures ANOVA (genotype/treatment $\times$ sex $\times$ sound level) was used for the I/O function. Short-term habituation ratios were determined by dividing the average of trials $25-30$ by the average of trials $1-2$ for each animal and were compared using a two-way ANOVA (genotype $\times$ sex). Prepulse inhibition was expressed as percentage of prepulse inhibition: $\% \mathrm{PPI}=[1-($ startle magnitude with prepulse/baseline startle without prepulse $\times 100]$. This indicated the amount that startle was inhibited, as a percentage of the baseline response. The average \%PPI for each prepulse type were calculated and compared using a four-way ANOVA (prepulse $\mathrm{dB}$ SPL $\times$ ISI $\times$ genotype $\times$ sex). For locomotor behavior, a three-way repeated-measures ANOVA (genotype $\times$ sex $\times$ time) was performed. The total distance traveled was analyzed using a two-way ANOVA (genotype $\times$ sex) and the time spent in the center or perimeter was analyzed separately from distance using a repeated-measures threeway ANOVA (genotype $\times$ sex $\times$ area). For CPP testing repeatedmeasures ANOVA (environment $\times$ virus) were performed, and the preference score was analyzed using a one-sample $t$ test. For analyzing in vivo and in vitro electrophysiology effects, paired $t$ tests and ANOVA were used as indicated.

\section{Results}

\section{ChAT::Cre rats exhibit normal startle, PPI, and locomotion}

To assess the potential role of cholinergic midbrain neurons in PPI, the light-sensitive ion cation channel ChR2 was expressed specifically in cholinergic midbrain neurons using a Credependent AAV vector injected stereotactically into the midbrain of transgenic ChAT::Cre rats. The ChAT and VAChT gene share a common locus. Because VAChT activity is the rate limiting step in cholinergic neurotransmission, transgenic ChAT::Cre rats, carrying additional copies of the VAChT gene, are potentially hypercholinergic, as it has been described for the respective transgenic mouse model (Kolisnyk et al., 2013; Prado et al., 2017). We therefore first measured startle reactivity, PPI, locomotion, and anxiety-like behavior in the transgenic ChAT::Cre rats and compared it to WT littermates. An I/O test showed that there was no significant main effect of genotype on startle reactivity, although WT rats trended to have higher startle amplitudes than the ChAT::Cre rats (Fig. 2A,B). Further analysis revealed that this was due to higher startle amplitudes in WT males compared with the other animals (Fig. 2C). Most importantly, ChAT::Cre animals had the same startle threshold as WT animals at intensities between 80 and $85 \mathrm{~dB}$. On subsequent testing days, all groups had similar baseline startle (Fig. 2D), and levels of PPI did not differ between ChAT::Cre animals and WT animals (Fig. 2E).

Next we tested whether ChAT::Cre rats were hyperlocomotive, as shown for the respective mouse model. There was no 
A

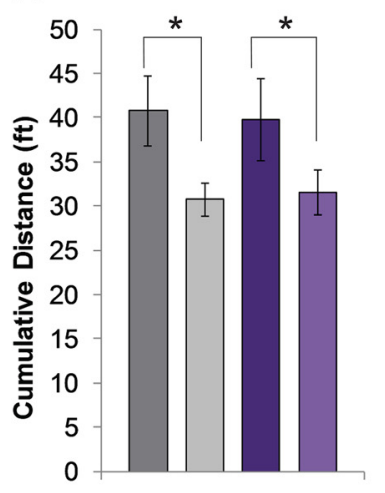

B

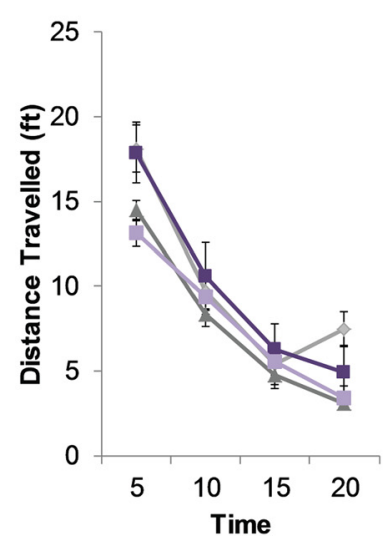

C

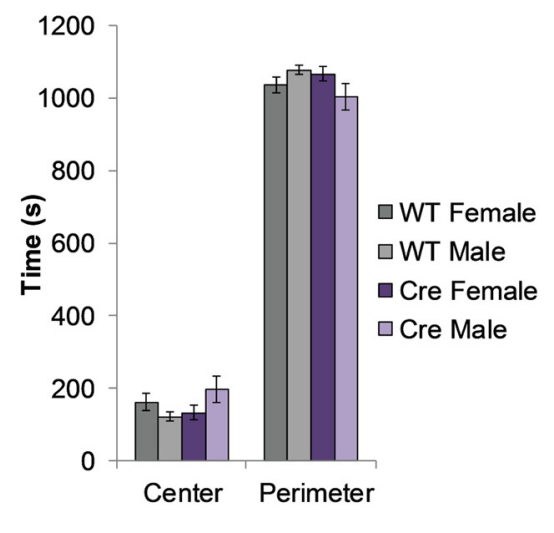

Figure 3. ChAT::Cre rats are not hyper-locomotive and do not show increased anxiety-like behavior. $A$, The cumulative distance traveled in 20 min was calculated and females traveled to a greater degree than their male counterparts in both genotypes $\left(F_{(1,27)}=10.4, p<0.01\right)$. There was no effect of genotype $\left(F_{(1,27)}=0.1, p=0.75\right)$. B, All groups habituated to the same degree over the 20 min testing period. $\boldsymbol{C}$, both genotypes displayed a strong preference for the perimeter of the open field $\left(F_{(1,27)}=522, p<0.001\right)$. This was equal across genotypes $\left(F_{(1,27)}=0.1, p=0.75\right)$ and $\operatorname{sexes}\left(F_{(1,27)}=0.14, p=0.71\right)$. Overall this demonstrates that locomotor activity and anxiety of transgenic rats was not different from WT animals. ${ }^{*} p<0.05$.

indication of a hyper-locomotive phenotype in ChAT:Cre rats. While female animals of both genotypes showed slightly higher locomotive activity than males, there was no significant difference between ChAT::Cre rats and WT in total distance traveled (Fig. 3A), in locomotor activity over time (Fig. 3B), or in time spent in center versus perimeter (Fig. $3 C$ ). The same ratio of time spent in the center versus perimeter also indicates that there are no differences in anxiety-like behavior, because anxious animals tend to spend more time at the perimeter along the walls.

\section{Optogenetic stimulation enhances startle}

We microinfused the optogenetic AAV vector rAAV5-EF1 $\alpha$ DIO-hChR2(H134R)-eYFP or control viral vector rAAV5-EF1 $\alpha$ DIO-eYFP locally into the PPTg of ChAT::Cre rats to transfect cholinergic cells with channelrhodopsin. Following microinfusion, bilateral light conductors were implanted to target the PPTg. Four weeks later we confirmed normal startle reactivity with an I/O function in both viral injection groups without optogenetic stimulation and found no differences (Fig. 4A,B). We then paired different amounts of optogenetic stimulation (3 pulses of $15 \mathrm{~ms}$, with $1 \mathrm{~s}, 85 \mathrm{~ms}$, or $5 \mathrm{~ms}$ ISI) with the startle stimulus onset. Whereas the lower frequencies had no impact on startle amplitudes, the $50 \mathrm{~Hz}$ application of bilateral optogenetic stimulation of cholinergic PPTg neurons potentiated startle response amplitudes in ChR2-expressing animals, but not in animals expressing the control virus (Fig. 4C), which is in contrast to our hypothesis that these neurons inhibit startle. Moreover, repeated light stimulation showed a persistent startle potentiating effect across at least 10 subsequent trials (Fig. 4D).

In a subsequent experiment, we applied optogenetic stimulation shortly before the startle stimulus at intervals commonly used for PPI experiments to see whether preceding stimulation of cholinergic PPTg neurons could mimic an acoustic prepulse (Fig. $5 A$ ). These trials were interspersed with startle only trials and trials with acoustic prepulses, at pseudorandomized order. As shown in Figure $5 B$, optogenetic stimulation before startle still enhanced startle responses, leading to negative PPI, or prepulse facilitation, across different intervals between photostimulation and acoustic stimulation, whereas acoustic prepulses greatly inhibited startle by $70-$ $95 \%$, as expected.
To confirm that the effects of optogenetic stimulation were indeed due to the activation of cholinergic neurons and to also gain some information about the respective cholinergic receptor class involved, we subsequently combined optogenetic stimulation with the administration of the nicotinic antagonist mecamylamine. We ran a combination of the startle protocol shown in Figures $4 A$ and $5 A$, with first simultaneous optogenetic stimulation and then startle preceding optogenetic stimulation at different ISI, intermingled with prepulse trials and startle only trials. Systemic injection of mecamylamine before startle testing inhibited the startle potentiating effect of both the concurrent optogenetic stimulation (Fig. 6A) as well as of the optogenetic stimulation preceding the startle sound in transgenic animals expressing ChR2 (Fig. 6B), although it had no significant effect in animals expressing control virus. This indicates that optogenetic activation of PPTg neurons and subsequent release of acetylcholine target excitatory nicotine receptors presumably expressed in the startle pathway. In summary, these optogenetic experiments indicate that activation of cholinergic PPTg neurons enhance startle through activation of nicotinic receptors and are therefore very likely not involved in mediating PPI.

To further verify that PPTg cholinergic neurons were indeed specifically activated in our experiments, all animals were analyzed port-mortem for expression of ChR2 in the PPTg and for the proper placement of light conductors (Fig. 7A). Immunohistochemical labeling using an antibody for ChT1 was used to quantify the percentage of PPTg cholinergic neurons expressing ChR2, and the percentage of ChR2 (YFP)-expressing neurons that are cholinergic (Fig. $7 B$ ). Overall, the ChR2(H134R)-YFP protein was expressed in $70 \%( \pm 11 \%)$ of $\mathrm{PPTg}$ cholinergic neurons, and the YFP control virus in 73\% ( $\pm 9 \%)$ of PPTg cholinergic neurons. Inversely, 95\% ( $\pm 4 \%)$ of ChR2(H134R)-YFPexpressing neurons, and $89 \%( \pm 4 \%)$ of cells expressing the control virus, were ChT1-positive. This confirmed that ChR2 was specifically expressed in the majority of PPTg cholinergic neurons, but not in noncholinergic neurons.

To assess whether photostimulation was effective in eliciting action potentials in ChR2-expressing PPTg neurons, we also killed three animals $90 \mathrm{~min}$ after optogenetic stimulation and stained for c-FOS to detect cellular activation (Fig. 7C). When analyzing coexpression of YPF with the cellular activation 
A
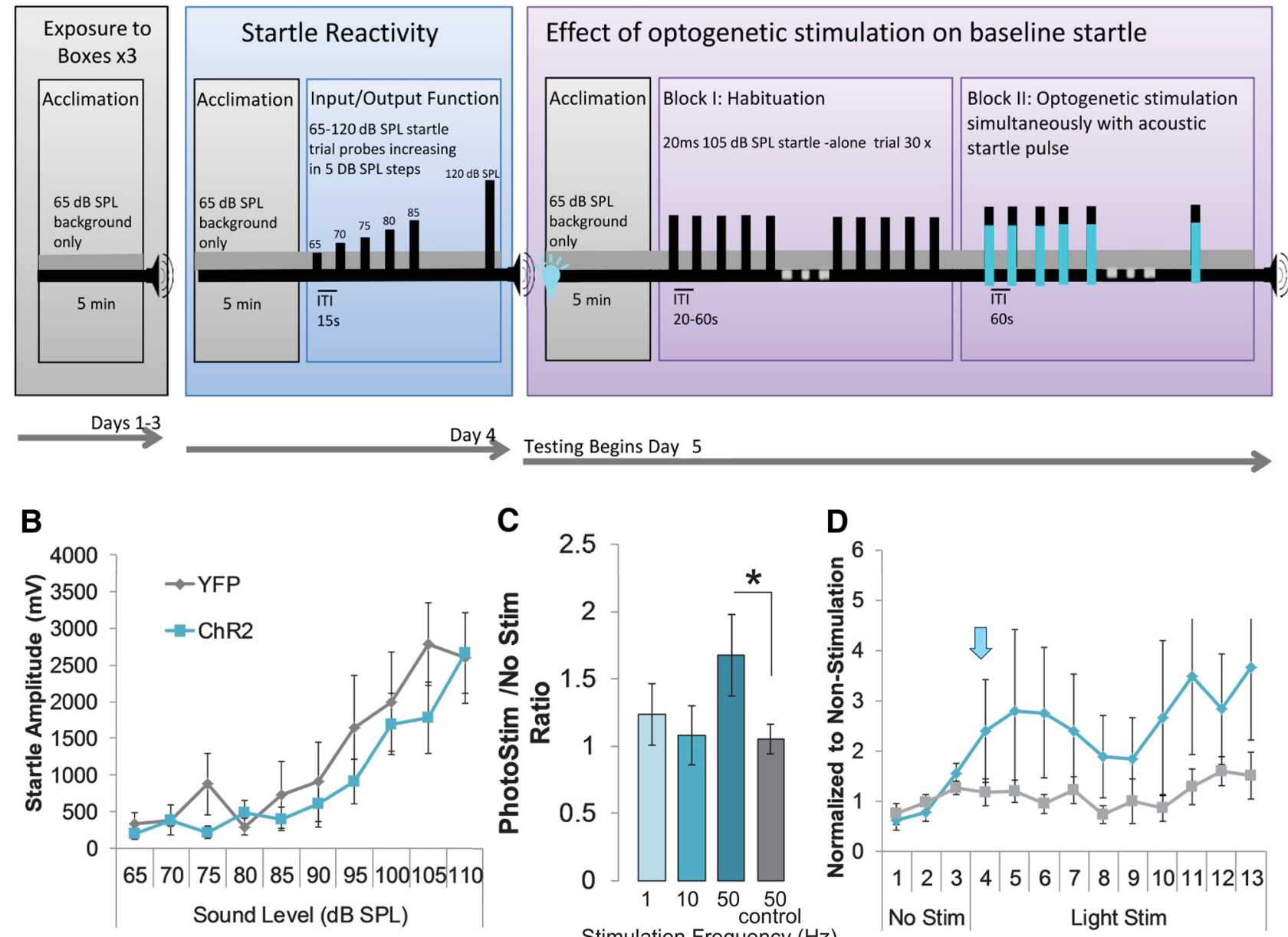

Figure 4. Optogenetic stimulation increases startle. $\boldsymbol{A}$, Schematic of the startle protocol with optogenetic stimulation represented in blue. $\boldsymbol{B}$, Startle reactivity (I/O function) was not different between animals inoculated with control virus and animals with the ChR2 virus, both of which were implanted with a light rod, without photostimulation (YFP: $n=6$, ChR2: $n=7, F_{(1,10)}=0.9$, $p=0.37)$. C, ChR2-expressing animals showed increased startle responses with $50 \mathrm{~Hz}$ light stimulation by a ratio of $1.82\left( \pm 0.32 ; t_{(11)}=2.23, p=0.04\right)$, but not with lower stimulation frequencies of $1 \mathrm{~Hz}$ and $10 \mathrm{~Hz}$. Control animals showed no change in startle magnitude with simultaneous optogenetic stimulation. $\boldsymbol{D}$, This increase in startle responses could be sustained by repeated optogenetic stimulation. The blue arrow indicates the first trial of startle paired with optogenetic stimulation. ${ }^{*} p<0.05$.

marker, we found that photostimulation induced c-FOS expression in $71 \%( \pm 13 \%)$ of ChR2(H134R)-YFP-expressing neurons, whereas only $8 \%( \pm 3 \%)$ of YFP-control virus expressing cells coexpressed c-FOS. In both YFP-control and ChR2(H134R)YFP-expressing animals non-YFP-labeled cells were also expressing c-FOS.

Last, we verified efficient stimulation of PPTg cholinergic neurons by running a positive behavioral control: a subset of the animals used for startle testing experiments shown above underwent a subsequent CPP test, because it has been shown that optogenetic stimulation of cholinergic PPTg neurons is sufficient to induce place preference (Xiao et al., 2016). One of the boxes was assigned to be paired with optogenetic stimulation and the other box to no stimulation (random). All animals were tethered during the training and testing sessions. After three training sessions for each box, ChR2(H134R)YFP-expressing animals exhibited a preference for the box paired with optogenetic stimulation at a subsequent testing day, whereas animal transfected with the control virus did not develop any preference for the box paired with photostimulation (Fig. $8 A, B$ ).

\section{Discussion}

\section{Prepulse inhibition of startle and the PPTg}

Our results show that specific activation of cholinergic midbrain neurons using an optogenetic approach generally enhances startle reactivity. PPI of startle is an operational measure to quantify sensory filtering. It does not require any learning and is largely independent of confounds like motivation and attention. As such, PPI is widely used in pre-clinical research. PPI disruptions are a hallmark of, schizophrenia (Braff et al., 1978, 1995; Geyer and Braff, 1982; Kunugi et al., 2007; Walters and Owen, 2007; Takahashi et al., 2008; Moriwaki et al., 2009; Perry et al., 2009), but are also observed in a variety of other neurodevelopmental/ psychiatric disorders, including ADHD and autism spectrum disorders (Swerdlow et al., 1995; Castellanos et al., 1996; Braff et al., 2001). PPI measurements are routinely used in drug-discovery, where the reversal of dopamine-induced PPI deficits in rats is a gold standard for antipsychotic drug screening. It has been shown that acoustic, tactile, and visual prepulses can induce PPI of acoustic startle (Hoffman and Ison, 1980), however, acoustic stimuli are primarily used for both prepulses and startle stimuli 
A
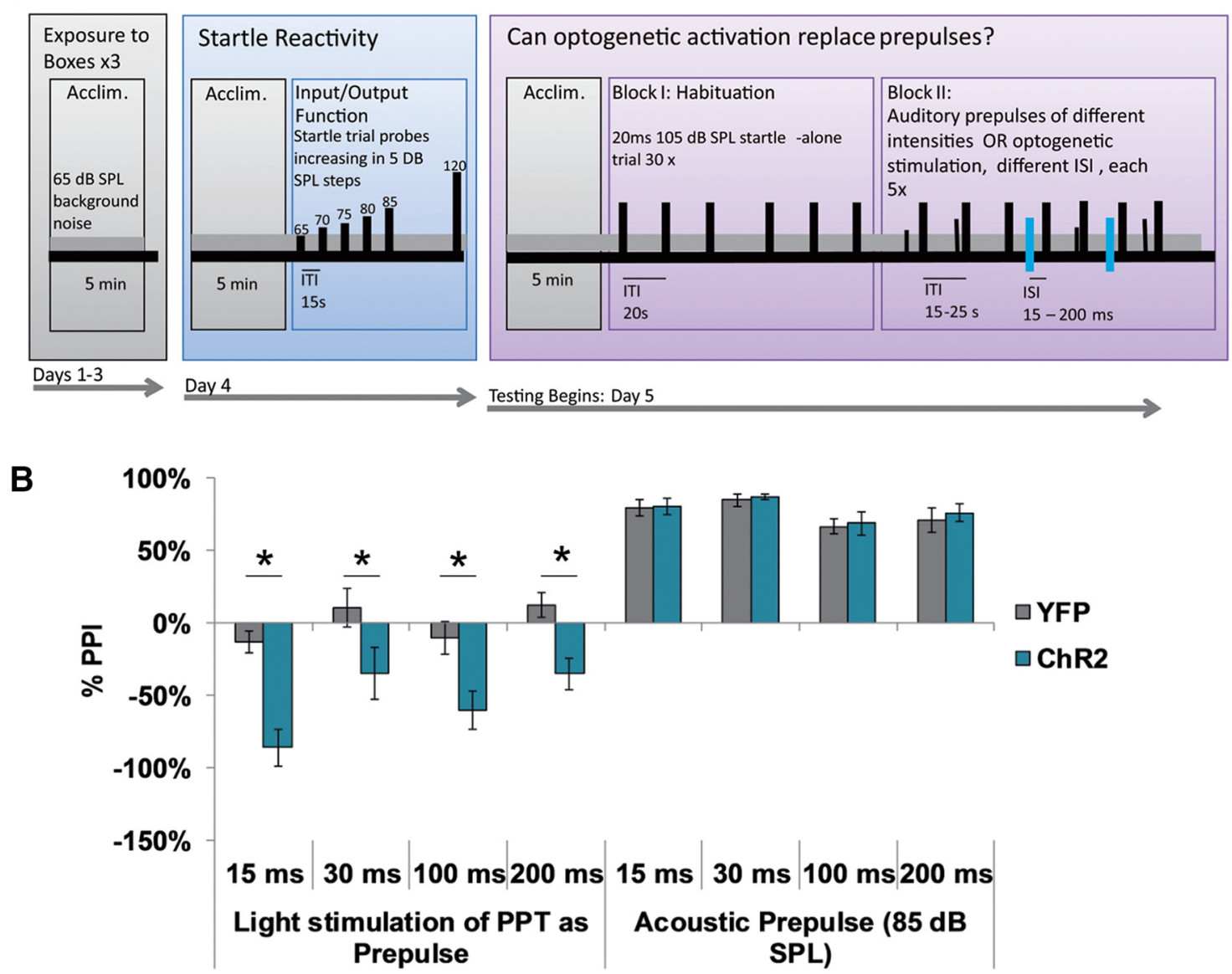

Figure 5. Optogenetic stimulation induces prepulse facilitation. $\boldsymbol{A}$, Schematic of the startle protocol with optogenetic stimulation represented in blue. $\boldsymbol{B}$, The amount of startle inhibition (\% PPI) was assessed using trials with acoustic prepulses or with short optogenetic stimulation at different interstimulus intervals, as indicated. Animals injected with control virus showed no change in startle amplitude through optogenetic stimulation whereas animals expressing ChR2 showed prepulse facilitation instead of PPI upon optogenetic stimulation $\left(F_{(1,5)}=17, p<0.01\right)$. Both groups showed normal PPI of $70-95 \%$ with acoustic prepulses. ${ }^{*} p<0.05$.

since they are easiest to experimentally control. The primary acoustic startle pathway has been established by previous work from us and others (Davis et al., 1982; Koch, 1999; Schmid and Weber, 2002; Yeomans et al., 2002; Schmid et al., 2003, 2010; Simons-Weidenmaier et al., 2006). Because PPI is fast, inhibiting startle within 8-12 ms after the prepulse, a short brainstem circuit mediating PPI is warranted (Mansbach and Geyer, 1991). A hypothetical PPI pathway has been published in papers and reviews, comprised of a short feedforward inhibitory loop in the midbrain (Fendt et al., 1994; Fendt and Koch, 1999; Koch, 1999; Figure 1). There is solid data from lesion studies and electrical simulations in vivo that support the participation of the inferior and superior colliculi in this PPI circuit (Fendt et al., 1994; Li et al., 1998a,b; Fendt, 1999; Li and Yeomans, 2000; Fendt et al., 2001; Li and Yue, 2002). Furthermore, the PPTg, known as pedunculopontine nucleus in humans, seems to be the central hub of this PPI pathway: lesions or inactivation of the PPT have been shown by multiple studies to robustly disrupt PPI (Swerdlow and Geyer, 1993; Fendt and Koch, 1999; Jones and Shannon, 2004; MacLaren et al., 2014). This implies an inhibitory projection from the PPT to the startle pathway, which mediates startle inhibition by a prepulse.

\section{Experimental limitations}

We found optogenetic stimulation effects in the PPTg on the startle magnitude at $50 \mathrm{~Hz}$ stimulation, but not at the two lower frequencies. It is important to mention that PPTg neuron firing might not necessarily following this frequency. The high-frequency stimulation is probably efficient because it provides sufficient amount of light and therefore membrane depolarization of ChR2-expressing neurons to make them fire action potentials. We used this high-frequency stimulation rather than constant stimulation for a longer time period to avoid any heat effects in the tissue (Suhan et al., 2017).

This study was focused on cholinergic cells in the PPTg, however, there is one study that suggests that cholinergic neurons in the adjacent laterodorsal tegmentum (LDT), rather than in the PPTg, play an important role in startle modulation (Jones and Shannon, 2004). In most of the animals in the present study, the LDT was also transfected with the viral constructs but often not to the same extend as the PPTg (data not shown). It is likely that the light stimulation by the implanted light conductors was efficient to activate ChR2-expressing cells in the LDT at least to some extent. While there is no evidence from our data that LDT cholinergic neurons might have an opposite effect on startle, we cannot entirely rule out a different role for LDT cholinergic neurons. However, we analyzed whether the optogenetic effects on baseline startle (Fig. 4D) correlated with the spread of the viral expression to the LDT, or the medial/lateral position of the optotrode, because there is a huge variability of the optogenetic stimulation effect between animals. We found no strong correlation, indicat- 


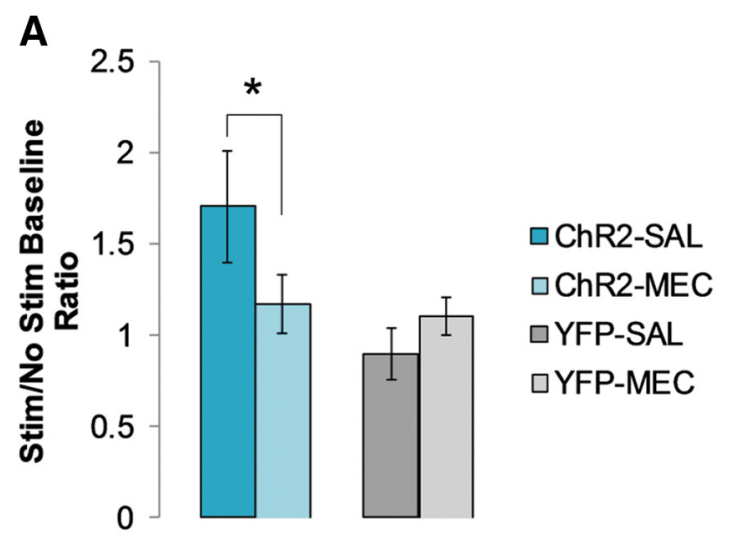

B

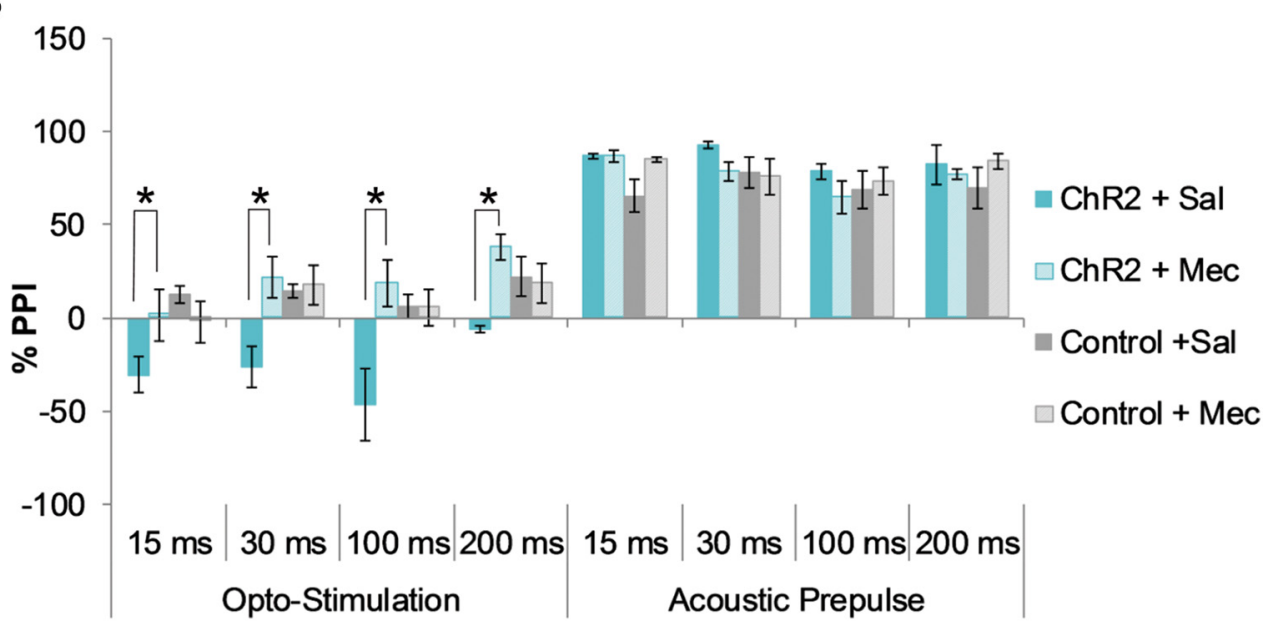

Figure 6. The nicotinic antagonist mecamylamine blocks the effect of optogenetic stimulation. $\boldsymbol{A}$, Administration of nicotinic antagonist mecamylamine blocked the increase in baseline startle reactivity through simultaneous optogenetic stimulation in ChR2-expressing animals $\left(F_{(1,11)}=15.6, p<0.01\right)$, whereas it had no significant effect on baseline startle in control animals. $\boldsymbol{B}$, In a separate group of animals, optogenetic stimulation caused a significant enhancement of startle magnitude in $C_{h R 2}$ animals, but not controls $\left(F_{(1,11)}=6.9, p=0.02 ; c_{1}\right.$ compare Fig. $\left.5 B\right)$. However, we found a significant interaction between drug and virus type $\left(F_{(1,11)}=6.2, p=0.03\right)$. Post hoc tests revealed that mecamylamine treatment completely blocked the optogenetically-induced increase in startle in the ChR2 animals $\left(t_{(6)}=2.5, p=0.04\right)$, whereas there was no effect of mecamylamine on PPI in the group with the control virus $\left(t_{(6)}=1.0, p=0.36\right)$. ${ }^{*} p<0.05$.

ing that the higher variability is due to differences in general viral transfection efficiency or the localization of the optic fiber.

\section{The role of cholinergic PPTg neurons revisited}

The PPTg is considered a cholinergic midbrain structure. Based on the findings that general lesions of the PPTg disrupt PPI (Koch et al., 1993; Swerdlow and Geyer, 1993), it has been assumed that PPI is mediated by cholinergic inhibition of the startle pathway on the level of the pons upon PPTg activation by a prepulse (Koch et al., 1993; Swerdlow and Geyer, 1993; Fendt and Koch, 1999; Jones and Shannon, 2000a,b; Fendt et al., 2001; Yeomans et al., 2006). Our study does not conflict with these previous studies showing the important role of the PPTg in PPI, given the fact that PPTg contains also GABAergic and glutamatergic neurons that were equally affected by general lesions in past studies. Our results clearly indicate, though, that inhibition of startle might not be executed by cholinergic PPTg neurons, but instead may be a function of GABAergic and/or glutamatergic cells in the PPTg. They could either directly project to the caudal pontine reticular formation (PnC), or indirectly inhibit the startle pathway, e.g., through GABAergic projections from the substantia nigra. Indeed, both GABA and metabotropic glutamate receptors have been shown to inhibit startle in vivo, and startle mediating neurons in the reticular formation in vitro (Schmid et al.,
2010; Yeomans et al., 2010). Furthermore, studies in cichlids, zebrafish and mice, have implied a crucial involvement of glutamatergic and/or GABAergic inhibition in PPI (Bergeron et al., 2015; Curtin and Preuss, 2015; Tabor et al., 2018).

What is the function of cholinergic PPTg neurons in modulating startle? Our data, together with the results of another recent study (MacLaren et al., 2014), indicate that cholinergic projections to the $\mathrm{PnC}$ increases startle much in accordance with the role of acetyl choline in arousal. As such, cholinergic input to the startle pathway could be involved in generally regulating and maintaining startle reactivity according to the arousal state of the subject. Furthermore, it has become apparent that cholinergic PPTg neuron activity carries information about emotional salience, since they are crucial for associative learning in the CPP paradigm (Xiao et al., 2016) and conditioned avoidance task (Bortolanza et al., 2010). In that regard they could also play a role in increasing PPI if the prepulse is emotionally salient (Zou et al., 2007). There is also some limited evidence that cholinergic mechanisms may play a role in long-term habituation of startle (Berón de Astrada and Maldonado, 1999; Schmid et al., 2011), or that these neurons could be involved in sensitization of startle, as arousal and sensitization have been linked in the past (Davis and Walker, 2014). Future experiments will address these hypotheses. 
A

B
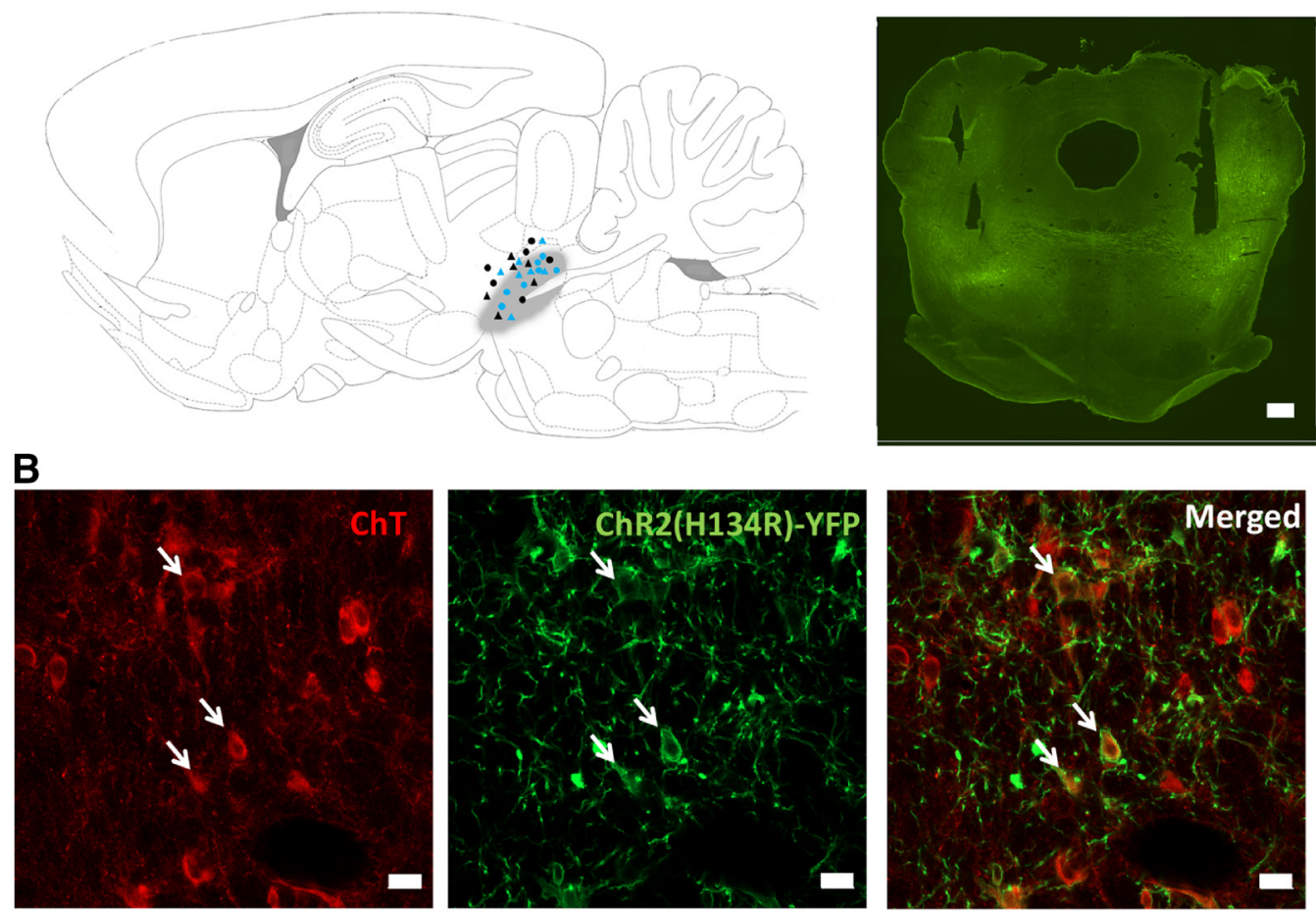

\section{C}
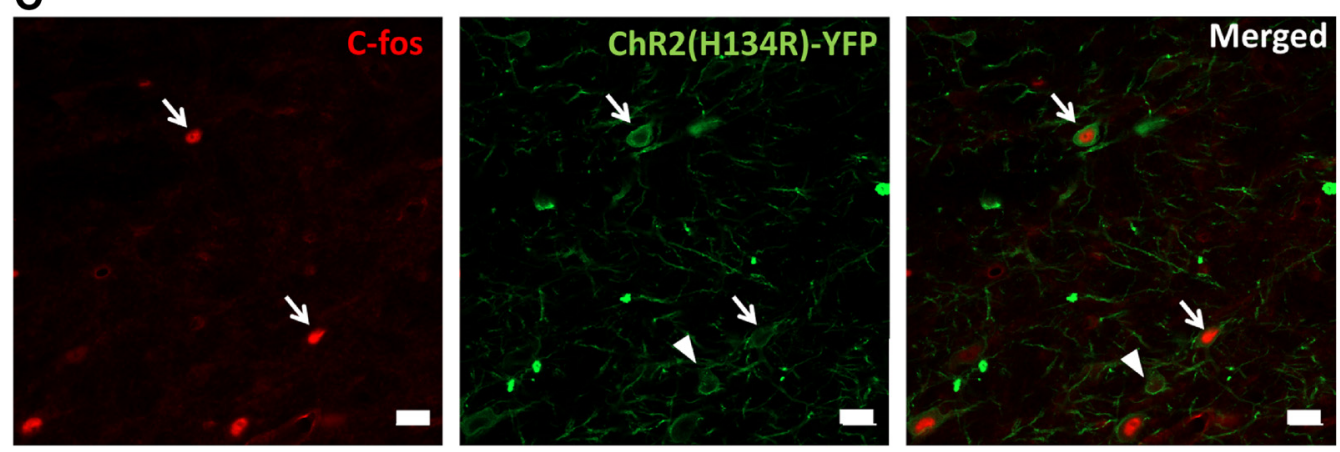

Figure 7. Quantification of ChR2 expression and c-FOS activation in ChR2-expressing cells. A, Scheme of a sagittal rat brain slice showing the PPTg in gray. Blue markers show the placements of the light fiber tips in ChR2-expressing animals, and black represents placements in controls. Triangles denote placement on the right side and dots on the left. Right, Representative image of the tracts of implanted light fibers is shown. Scale bar, $500 \mu \mathrm{m} . \boldsymbol{B}$, Expression of ChR2 and its coexpression with the cholinergic marker ChT. Arrows point to some examples of double-labeled cells. Quantitative analysis revealed substantial overlap of ChT and YFP expression (see Results). C, Double-labeling for the cellular activation marker c-FOS with the viral YFP tag. Substantial coexpression of c-FOS and ChR2 was observed (white arrows), plus some occasional c-FOS stained cells that were not YFP-positive (arrowhead). Scale bars, $25 \mu \mathrm{m}$.

A

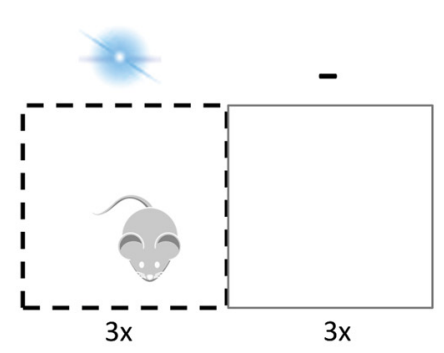

B

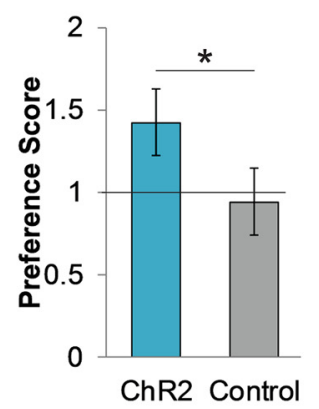

C

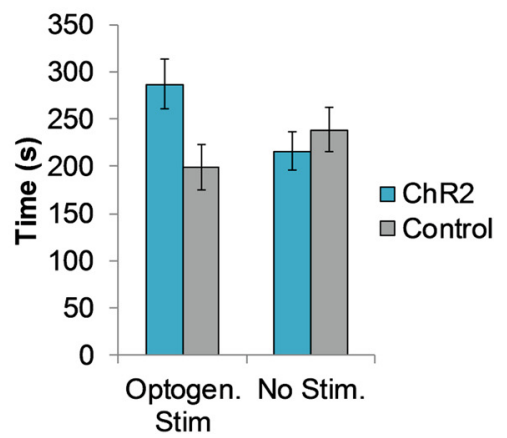

Figure 8. Optogenetic stimulation caused CPP. $\boldsymbol{A}$, Schematic showing the set up for CPP: one box was paired with optogenetic stimulation, the other box with no stimulation. $\boldsymbol{B}$, ChR2-expressing animals tended to spend more time in the environment paired with photostimulation $\left(F_{(1,10)}=4.3, p=0.06 ; n=6\right.$ per group). $C$, A preference score was calculated for each animal (time spent in paired box/time spent in unpaired box). ChR2-expressing animals had a significantly increased preference score of $1.42 \pm 0.2\left(t_{(5)}=2.3, p=0.03\right)$, whereas control virus-expressing animals did not develop any place preference upon light stimulation. ${ }^{*} p<0.05$. 


\section{Conclusion}

In summary, the results of this study indicate that the role of cholinergic neurotransmission in regulating startle has to be redefined: cholinergic input from the PPTg seem to be important for maintaining high startle reactivity in accordance with their role in arousal. In contrast to the general view, they seem not to be involved in mediating prepulse inhibition. This calls for a revision of the long-standing hypothetical pathway mediating PPI.

\section{References}

Ahmad T, Lauzon NM, de Jaeger X, Laviolette SR (2013) Cannabinoid transmission in the prelimbic cortex bidirectionally controls opiate reward and aversion signaling through dissociable kappa versus $\mu$-opiate receptor dependent mechanisms. J Neurosci 33:15642-15651. CrossRef Medline

Alderson HL, Latimer MP, Blaha CD, Phillips AG, Winn P (2004) An examination of $\mathrm{D}$-amphetamine self-administration in pedunculopontine tegmental nucleus-lesioned rats. Neuroscience 125:349-358. CrossRef Medline

Bergeron SA, Carrier N, Li GH, Ahn S, Burgess HA (2015) Gsxl expression defines neurons required for prepulse inhibition. Mol Psychiatry 20: 974-985. CrossRef Medline

Berón de Astrada M, Maldonado H (1999) Two related forms of long-term habituation in the crab chasmagnathus are differentially affected by scopolamine. Pharmacol Biochem Behav 63:109-118. CrossRef Medline

Bortolanza M, Wietzikoski EC, Boschen SL, Dombrowski PA, Latimer M, Maclaren DA, Winn P, Da Cunha C (2010) Functional disconnection of the substantia nigra pars compacta from the pedunculopontinenucleus impairs learning of a conditioned avoidance task. Neurobiol Learn Mem 94:229-239. CrossRef Medline

Bosch D, Schmid S (2006) Activation of muscarinic cholinergic receptors inhibits giant neurones in the caudal pontine reticular nucleus. Eur J Neurosci 24:1967-1975. CrossRef Medline

Bosch D, Schmid S (2008) Cholinergic mechanism underlying prepulse inhibition of the startle response in rats. Neuroscience 155:326-335. CrossRef Medline

Braff D, Stone C, Callaway E, Geyer M, Glick I, Bali L (1978) Prestimulus effects on human startle reflex in normals and schizophrenics. Psychophysiology 15:339-343. CrossRef Medline

Braff DL, Swerdlow NR, Geyer MA (1995) Gating and habituation deficits in the schizophrenia disorders. Clin Neurosci 3:131-139. Medline

Braff DL, Geyer MA, Swerdlow NR (2001) Human studies of prepulse inhibition of startle: normal subjects, patient groups, and pharmacological studies. Psychopharmacology 156:234-258. CrossRef Medline

Castellanos FX, Fine EJ, Kaysen D, Marsh WL, Rapoport JL, Hallett M (1996) Sensorimotor gating in boys with Tourette's syndrome and ADHD: preliminary results. Biol Psychiatry 39:33-41. CrossRef Medline

Curtin PC, Preuss T (2015) Glycine and GABAA receptors mediate tonic and phasic inhibitory processes that contribute to prepulse inhibition in the goldfish startle network. Front Neural Circuits 9:12. CrossRef Medline

Cyr M, Parent MJ, Mechawar N, Rosa-Neto P, Soucy JP, Clark SD, Aghourian M, Bedard MA (2015) Deficit in sustained attention following selective cholinergic lesion of the pedunculopontine tegmental nucleus in rat, as measured with both post-mortem immunocytochemistry and in vivo PET imaging with $\left[{ }^{18} \mathrm{~F}\right]$ fluoroethoxybenzovesamicol. Behav Brain Res 278: 107-114. CrossRef Medline

Davis M, Walker DL (2014) Role of bed nucleus of the stria terminalis and amygdala AMPA receptors in the development and expression of context conditioning and sensitization of startle by prior shock. Brain Struct Funct 219:1969-1982. CrossRef Medline

Davis M, Gendelman DS, Tischler MD, Gendelman PM (1982) A primary acoustic startle circuit: lesion and stimulation studies. J Neurosci 2:791805. CrossRef Medline

Fendt M (1999) Enhancement of prepulse inhibition after blockade of GABA activity within the superior colliculus. Brain Res 833:81-85. CrossRef Medline

Fendt M, Koch M (1999) Cholinergic modulation of the acoustic startle response in the caudal pontine reticular nucleus of the rat. Eur J Pharmacol 370:101-107. CrossRef Medline

Fendt M, Koch M, Schnitzler HU (1994) Sensorimotor gating deficit after lesions of the superior colliculus. Neuroreport 5:1725-1728. CrossRef Medline

Fendt M, Li L, Yeomans JS (2001) Brain stem circuits mediating prepulse inhibition of the startle reflex. Psychopharmacology 156:216-224. CrossRef Medline

Fenton WS, Stover EL, Insel TR (2003) Breaking the log-jam in treatment development for cognition in schizophrenia: NIMH perspective. Psychopharmacology 169:365-366. CrossRef Medline

Garcia-Rill E, Luster B, D’Onofrio S, Mahaffey S (2015) Arousal, motor control, and Parkinson's disease. Transl Neurosci 6:198-207. CrossRef Medline

Geyer MA, Braff DL (1982) Habituation of the blink reflex in normals and schizophrenic patients. Psychophysiology 19:1-6. CrossRef Medline

Green MF (1996) What are the functional consequences of neurocognitive deficits in schizophrenia? Am J Psychiatry 153:321-330. CrossRef Medline

Gut NK, Winn P (2016) The pedunculopontine tegmental nucleus: a functional hypothesis from the comparative literature. Mov Disord 31:615624. CrossRef Medline

Hoffman HS, Ison JR (1980) Reflex modification in the domain of startle: I. Some empirical findings and their implications for how the nervous system processes sensory input. Psychol Rev 87:175-189. CrossRef Medline

Jones CK, Shannon HE (2000a) Muscarinic cholinergic modulation of prepulse inhibition of the acoustic startle reflex. J Pharmacol Exp Ther 294: 1017-1023. Medline

Jones CK, Shannon HE (2000b) Effects of scopolamine in comparison with apomorphine and phencyclidine on prepulse inhibition in rats. Eur J Pharmacol 391:105-112. CrossRef Medline

Jones CK, Shannon HE (2004) Lesions of the laterodorsal tegmental nucleus disrupt prepulse inhibition of the acoustic startle reflex. Pharmacol Biochem Behav 78:229-237. CrossRef Medline

Koch M (1999) The neurobiology of startle. Prog Neurobiol 59:107-128. CrossRef Medline

Koch M, Kungel M, Herbert H (1993) Cholinergic neurons in the pedunculopontine tegmental nucleus are involved in the mediation of prepulse inhibition of the acoustic startle response in the rat. Exp Brain Res 97:7182. Medline

Kolisnyk B, Guzman MS, Raulic S, Fan J, Magalhães AC, Feng G, Gros R, Prado VF, Prado MA (2013) ChAT-ChR2-EYFP mice have enhanced motor endurance but show deficits in attention and several additional cognitive domains. J Neurosci 33:10427-10438. CrossRef Medline

Kunugi H, Tanaka M, Hori H, Hashimoto R, Saitoh O, Hironaka N (2007) Prepulse inhibition of acoustic startle in Japanese patients with chronic schizophrenia. Neurosci Res 59:23-28. CrossRef Medline

Laviolette SR, van der Kooy D (2003) Blockade of mesolimbic dopamine transmission dramatically increases sensitivity to the rewarding effects of nicotine in the ventral tegmental area. Mol Psychiatry 8:50-59,9. CrossRef Medline

Li L, Yeomans JS (2000) Using intracranial electrical stimulation to study the timing of prepulse inhibition of the startle reflex. Brain Res Brain Res Protoc 5:67-74. CrossRef Medline

Li L, Yue Q (2002) Auditory gating processes and binaural inhibition in the inferior colliculus. Hear Res 168:98-109. CrossRef Medline

Li L, Priebe RP, Yeomans JS (1998a) Prepulse inhibition of acoustic or trigeminal startle of rats by unilateral electrical stimulation of the inferior colliculus. Behav Neurosci 112:1187-1198. CrossRef Medline

Li L, Korngut LM, Frost BJ, Beninger RJ (1998b) Prepulse inhibition following lesions of the inferior colliculus: prepulse intensity functions. Physiol Behav 65:133-139. CrossRef Medline

Liu X, Ramirez S, Pang PT, Puryear CB, Govindarajan A, Deisseroth K, Tonegawa $S$ (2012) Optogenetic stimulation of a hippocampal engram activates fear memory recall. Nature 484:381-385. CrossRef Medline

Machold RP (2013) Loss of rostral brainstem cholinergic activity results in decreased ultrasonic vocalization behavior and altered sensorimotor gating. Behav Brain Res 256:51-55. CrossRef Medline

MacLaren DA, Markovic T, Clark SD (2014) Assessment of sensorimotor gating following selective lesions of cholinergic pedunculopontine neurons. Eur J Neurosci 40:3526-3537. CrossRef Medline

Mansbach RS, Geyer MA (1991) Parametric determinants in pre-stimulus modification of acoustic startle: interaction with ketamine. Psychopharmacology 105:162-168. CrossRef Medline

Mori F, Okada KI, Nomura T, Kobayashi Y (2016) The pedunculopontine 
tegmental nucleus as a motor and cognitive interface between the cerebellum and basal ganglia. Front Neuroanat 10:109. CrossRef Medline

Moriwaki M, Kishi T, Takahashi H, Hashimoto R, Kawashima K, Okochi T, Kitajima T, Furukawa O, Fujita K, Takeda M, Iwata N (2009) Prepulse inhibition of the startle response with chronic schizophrenia: a replication study. Neurosci Res 65:259-262. CrossRef Medline

Perry W, Minassian A, Paulus MP, Young JW, Kincaid MJ, Ferguson EJ, Henry BL, Zhuang X, Masten VL, Sharp RF, Geyer MA (2009) A reverse-translational study of dysfunctional exploration in psychiatric disorders: from mice to men. Arch Gen Psychiatry 66:1072-1080. CrossRef Medline

Pinnock F, Bosch D, Brown T, Simons N, Yeomans JR, DeOliveira C, Schmid S (2015) Nicotine receptors mediating sensorimotor gating and its enhancement by systemic nicotine. Front Behav Neurosci 9:30. CrossRef Medline

Prado VF, Janickova H, Al-Onaizi MA, Prado MA (2017) Cholinergic circuits in cognitive flexibility. Neuroscience 345:130-141. CrossRef Medline

Schindelin J, Arganda-Carreras I, Frise E, Kaynig V, Longair M, Pietzsch T, Preibisch S, Rueden C, Saalfeld S, Schmid B, Tinevez JY, White DJ, Hartenstein V, Eliceiri K, Tomancak P, Cardona A (2012) Fiji: an opensource platform for biological-image analysis. Nat Methods 9:676-682. CrossRef Medline

Schmid S, Weber M (2002) Neurons of the superior olivary complex do not excite startle-mediating neurons in the caudal pontine reticular formation. Neuroreport 13:2223-2227. CrossRef Medline

Schmid S, Simons NS, Schnitzler HU (2003) Cellular mechanisms of the trigeminally evoked startle response. Eur J Neurosci 17:1438-1444. CrossRef Medline

Schmid S, Brown T, Simons-Weidenmaier N, Weber M, Fendt M (2010) Group III metabotropic glutamate receptors inhibit startle-mediating giant neurons in the caudal pontine reticular nucleus but do not mediate synaptic depression/short-term habituation of startle. J Neurosci 30: 10422-10430. CrossRef Medline

Schmid S, Azzopardi E, De Jaeger X, Prado MA, Prado VF (2011) VAChT knock-down mice show normal prepulse inhibition but disrupted longterm habituation. Genes Brain Behav 10:457-464. CrossRef Medline

Schneider CA, Rasband WS, Eliceiri KW (2012) NIH image to ImageJ: 25 years of image analysis. Nat Methods 9:671-675. CrossRef Medline

Simons-Weidenmaier NS, Weber M, Plappert CF, Pilz PK, Schmid S (2006) Synaptic depression and short-term habituation are located in the sensory part of the mammalian startle pathway. BMC Neurosci 7:38. CrossRef Medline

Sinclair D, Oranje B, Razak KA, Siegel SJ, Schmid S (2017) Sensory processing in autism spectrum disorders and fragile $\mathrm{X}$ syndrome: from the clinic to animal models. Neurosci Biobehav Rev 76:235-253. CrossRef Medline

Steidl S, Miller AD, Blaha CD, Yeomans JS (2011) M(5) muscarinic receptors mediate striatal dopamine activation by ventral tegmental morphine and pedunculopontine stimulation in mice. PloS One 6:e27538. CrossRef Medline

Suhan S, Ilona S, Chih-Chieh C, Isabelle D, Stéphane P, Antoine C, Claire M, Frédéric $P$ (2017) Experimental assessment of the safety and potential efficacy of high irradiance photostimulation of brain tissues. Sci Rep 7:43997. CrossRef Medline

Swerdlow NR, Geyer MA (1993) Prepulse inhibition of acoustic startle in rats after lesions of the pedunculopontine tegmental nucleus. Behav Neurosci 107:104-117. CrossRef Medline
Swerdlow NR, Paulsen J, Braff DL, Butters N, Geyer MA, Swenson MR (1995) Impaired prepulse inhibition of acoustic and tactile startle response in patients with Huntington's disease. J Neurol Neurosurg Psychiatry 58:192-200. CrossRef Medline

Tabor KM, Smith TS, Brown M, Bergeron SA, Briggman KL, Burgess HA (2018) Presynaptic inhibition selectively gates auditory transmission to the brainstem startle circuit. Curr Biol 28:2527-2535.e8. CrossRef Medline

Takahashi H, Iwase M, Ishii R, Ohi K, Fukumoto M, Azechi M, Ikezawa K, Kurimoto R, Canuet L, Nakahachi T, Iike N, Tagami S, Morihara T, Okochi M, Tanaka T, Kazui H, Yoshida T, Tanimukai H, Yasuda Y, Kudo $\mathrm{T}$, et al. (2008) Impaired prepulse inhibition and habituation of acoustic startle response in Japanese patients with schizophrenia. Neurosci Res 62:187-194. CrossRef Medline

Thompson JA, Felsen G (2013) Activity in mouse pedunculopontine tegmental nucleus reflects action and outcome in a decision-making task. J Neurophysiol 110:2817-2829. CrossRef Medline

Valsamis B, Schmid S (2011) Habituation and prepulse inhibition of the acoustic startle in rodents. J Vis Exp 55:e3446. CrossRef Medline

Walters JT, Owen MJ (2007) Endophenotypes in psychiatric genetics. Mol Psychiatry 12:886-890. CrossRef Medline

Wang HL, Morales M (2009) Pedunculopontine and laterodorsal tegmental nuclei contain distinct populations of cholinergic, glutamatergic and GABAergic neurons in the rat. Eur J Neurosci 29:340-358. CrossRef Medline

Winn P (2008) Experimental studies of pedunculopontine functions: are they motor, sensory or integrative? Parkinsonism Relat Disord 14:S194198. CrossRef Medline

Witten IB, Steinberg EE, Lee SY, Davidson TJ, Zalocusky KA, Brodsky M, Yizhar O, Cho SL, Gong S, Ramakrishnan C, Stuber GD, Tye KM, Janak PH, Deisseroth K (2011) Recombinase-driver rat lines: tools, techniques, and optogenetic application to dopamine-mediated reinforcement. Neuron 72:721-733. CrossRef Medline

Xiao C, Cho JR, Zhou C, Treweek JB, Chan K, McKinney SL, Yang B, Gradinaru V (2016) Cholinergic mesopontine signals govern locomotion and reward through dissociable midbrain pathways. Neuron 90:333-347. CrossRef Medline

Yamamoto K, Tanei ZI, Hashimoto T, Wakabayashi T, Okuno H, Naka Y, Yizhar O, Fenno LE, Fukayama M, Bito H, Cirrito JR, Holtzman DM, Deisseroth K, Iwatsubo T (2015) Chronic optogenetic activation augments $A \beta$ pathology in a mouse model of Alzheimer disease. Cell Rep 11:859-865. CrossRef Medline

Yeomans JS (2012) Muscarinic receptors in brain stem and mesopontine cholinergic arousal functions. Handb Exp Pharmacol 208:243-259. CrossRef Medline

Yeomans JS, Li L, Scott BW, Frankland PW (2002) Tactile, acoustic and vestibular systems sum to elicit the startle reflex. Neurosci Biobehav Rev 26:1-11. CrossRef Medline

Yeomans JS, Lee J, Yeomans MH, Steidl S, Li L (2006) Midbrain pathways for prepulse inhibition and startle activation in rat. Neuroscience 142 : 921-929. CrossRef Medline

Yeomans JS, Bosch D, Alves N, Daros A, Ure RJ, Schmid S (2010) GABA receptors and prepulse inhibition of acoustic startle in mice and rats. Eur J Neurosci 31:2053-2061. CrossRef Medline

Zou D, Huang J, Wu X, Li L (2007) Metabotropic glutamate subtype 5 receptors modulate fear-conditioning induced enhancement of prepulse inhibition in rats. Neuropharmacology 52:476-486. CrossRef Medline 